\title{
Quality of Life in Patients with Spinal Cord Injury: A Prospective Longitudinal Study
}

\author{
Alok Anshu' ${ }^{10}$ Shashivadhanan Sundaravadhanan ${ }^{10}$ \\ ${ }^{1}$ Department of Surgery, Armed Force Service Hospital, Kanpur, Uttar \\ Pradesh, India \\ Address for correspondence Sqn Ldr Alok Anshu, MS (Gen Surgery), \\ Department of Surgery, 7 Air Force Hospital, Kanpur, Uttar Pradesh \\ Indian J Neurotrauma 2023;20:18-23. \\ 208004, India (e-mail: dralokanshu@gmail.com).
}

\begin{abstract}
Keywords

- spinal cord injury

- World Health Organization Quality of Life Questionnaire

- predictors of QOL
\end{abstract}

Introduction Spinal cord injury $(\mathrm{SCl})$ is one field of neurotrauma where fierce research has been going on to achieve a cure for the dreaded disease. Complete cure of this condition still remains elusive. Although focus is mainly on reversing the physical disability, not much importance is given to other factors which have an immense bearing on quality of life (QOL) of the victim. These factors include social health, psychological health, and environmental factors. The Indian Armed Forces offers the unique advantage of following up a patient from the time of injury till rehabilitation. This prospective longitudinal study is the first of its kind in India, undertaken to assess the $\mathrm{QOL}$ of the $\mathrm{SCl}$ patient from the time of trauma till end of 1 year. We have attempted to measure $\mathrm{QOL}$ of the $\mathrm{SCl}$ patients in four main domains (physical health, psychological health, social health, and environmental factors) and further tried to highlight the predictors which play a major role in improving QOL. It is proposed that identifying these important predictors and correcting them with appropriate targeted interventions can play a major role in improving the $\mathrm{QOL}$ in $\mathrm{SCl}$ patients.

Materials and Methods This prospective longitudinal study was carried out in a single tertiary care hospital from May 2017 to October 2019. All patients with SCl were treated and followed up for at least 1 year posttrauma using the World Health Organization Quality of Life-BREF questionnaire. A total of 68 patients were treated and studied. Results were analyzed and conclusions drawn.

Observations and Results Physical health was the most important domain to have an impact on QOL while environmental health had the least. Maximum improvement occurred in all domains during the first 6 months after which the improvement in scores was unimpressive. The degree of improvement correlated directly to the severity of initial motor deficits. Strong caregivers' support and structured care in a rehabilitation center played important role in improving the $\mathrm{QOL}$ of $\mathrm{SCl}$ patients.

Conclusion Our study goes on to prove that in order to improve QOL of SCl patients an assessment needs to be undertaken going beyond physical domain. Factors playing a major role in deciding QOL should be identified and then subsequently be corrected with targeted interventions. article published online February 23, 2021
DOI https://doi.org/ $10.1055 / \mathrm{s}-0041-1725570$. ISSN 0973-0508.
(C) 2021. The Author(s).

This is an open access article published by Thieme under the terms of the Creative Commons Attribution License, permitting unrestricted use, distribution, and reproduction so long as the original work is properly cited. (https://creativecommons.org/licenses/by/4.0/)

Thieme Medical and Scientific Publishers Pvt. Ltd., A-12, 2nd Floor, Sector 2, Noida-201301 UP, India 


\section{Introduction}

Spinal cord injury (SCI) is one of the most disruptive traumatic events in any human's life. SCI may cause quadriplegia or paraplegia depending on the level of injury affecting the functioning of limbs, trunk, pelvic organs, bladder, and bowel, as well as sexual function. This loss of function leads to significant changes in life of the affected individual making routine vocational, social, sexual, and recreational activities impossible. Shortly after the injury, all attention is put into stabilizing the patient. Following the acute phase of definitive management, individual is left to cope with challenges thrown to him at physical, social, environmental, and psychological levels.

Limited knowledge exists as on date regarding analysis of factors influencing quality of life (QOL) in SCI on long term. Number of studies has explored how personal factors are associated with subjective QOL. Few studies have included environmental and personal factors in their same analysis, and yet even fewer have been longitudinal in nature. No prospective studies have been conducted in India so far to assess the QOL of patients with $\mathrm{SCI}$ on a long-term basis. This study is an attempt to measure the QOL of the SCI patients, and further tries to highlight the predictors which could play a major role in improving the QOL in these patients with appropriate interventions.

\section{Materials and Methods}

This was a prospective longitudinal study in which each patient with SCI reporting to a single tertiary care hospital in southern India were treated and followed up for 2 years. The World Health Organization Quality of Life (WHO QOL-BREF) questionnaire was given to them at time of presentation to treatment facility (within 48 hours of trauma). The same questionnaire was given to them at 6th month and then at end of 1 year following trauma. Results were analyzed and conclusions drawn. Any patient above the age of 18 years was included in the study. Patients with concomitant head injury or history of psychiatric illness were excluded from this study. A total of 72 patients were enrolled in this study after taking ethical clearance from the hospital ethical committee. By the end of 2 years 68 patients completed this study, which was conducted from May 2017 to October 2019. This action was in line with WHO QOL-BREF recommendations. According to the same recommendations, participants were oriented to answer the questionnaire based on the previous responses.

Measures and instruments used: The WHO QOL-BREF questionnaire was the primary tool to collect information on QOL of SCI patients. All 26 items in the WHO QOL-BREF are based on a five-point Likert scale. Among these items, 24 items are grouped under four domains of QOL: physical health (7 items), psychological well-being (6 items), social relationships (3 items), and environment ( 8 items). The 24 items in the domains are as follows:

1. Physical health activities of daily living:

- Dependence on medicinal substances and medical aids.

- Energy and fatigue.
- Mobility.

- Pain and discomfort.

- Sleep and rest.

- Work capacity.

2. Psychological bodily image and appearance:

- Negative feelings.

- Positive feelings.

- Self-esteem.

- Spirituality/religion/personal beliefs.

- Thinking, learning, memory, and concentration.

3. Social relationships:

- Personal relationships.

- Social support.

- Sexual activity.

4. Environment:

- Financial resources.

- Freedom, physical safety, and security.

- Health and social care: accessibility and quality.

- Home environment.

- Opportunities for acquiring new information and skills.

- Participation in and opportunities for recreation/ leisure activities.

- Physical environment (pollution/noise/traffic/climate).

- Transport.

Scoring in WHO QOL-BREF: The four domain scores denote an individual's perception of $\mathrm{QOL}$ in each particular domain. Domain scores are scaled in a positive direction (i.e., higher scores denote higher QOL). The mean score of items within each domain is used to calculate the domain score. The WHO QOL-BREF questionnaire was scored after its administration to the study subjects and the raw scores were converted to transformed scores. The first transformation converts scores to a range of 4 to 20 and the second transformation converts domain scores to a 0 to 100 scale. Higher scores reflect a better QOL.

\section{Observation}

Physical health: WHO QOL was assessed for each patient using WHO QOL questionnaire. At onset of injury, total physical health score mean was 64.66 . For the cervical subgroup it was 60.69 , for thoracic 63.5 , for lumbar 67.96 , and for sacral 77. At 6 months postinjury the mean score was 72.49 , for the cervical subgroup it was 71.76 , for thoracic 70.29 , for lumbar 73.2 , and for sacral 82 . At 1 year postinjury the mean score was 78.94 , for the cervical subgroup it was 78.76 , for thoracic 78 , for lumbar 78.92, and for sacral 84.67 (-Figs. 1-2).

The factors which played major role in first month were pain and discomfort. At the end of 6 months, the pain factor regressed in order of importance while factors like pressure sore, dysreflexia, urinary tract infection, and spasticity were the major factors. At the end of 1 year, mobility and work capacity were the major determinants of physical health domain QOL.

Psychological health: At onset of injury, total psychological health score mean was 66.81 . For the cervical subgroup it 


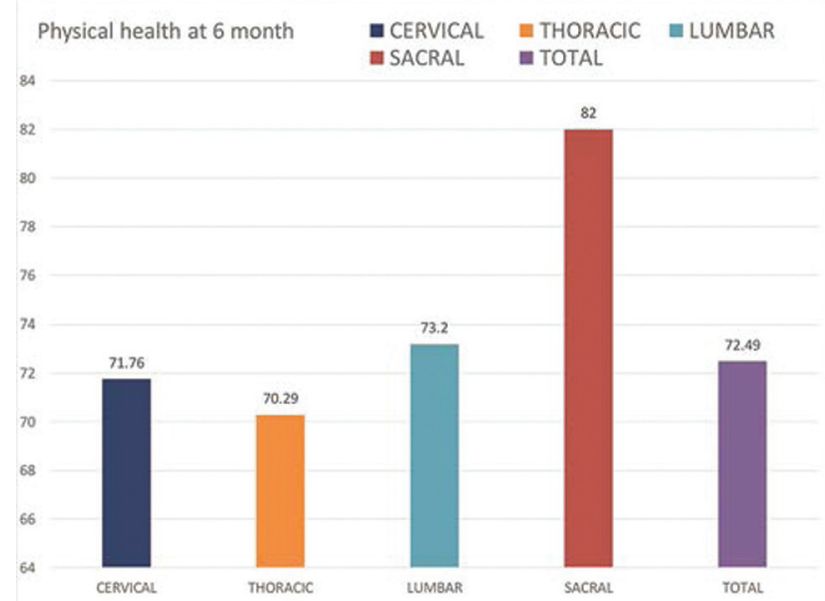

Fig. 1 Bar chart showing physical health domain score at 6 months.

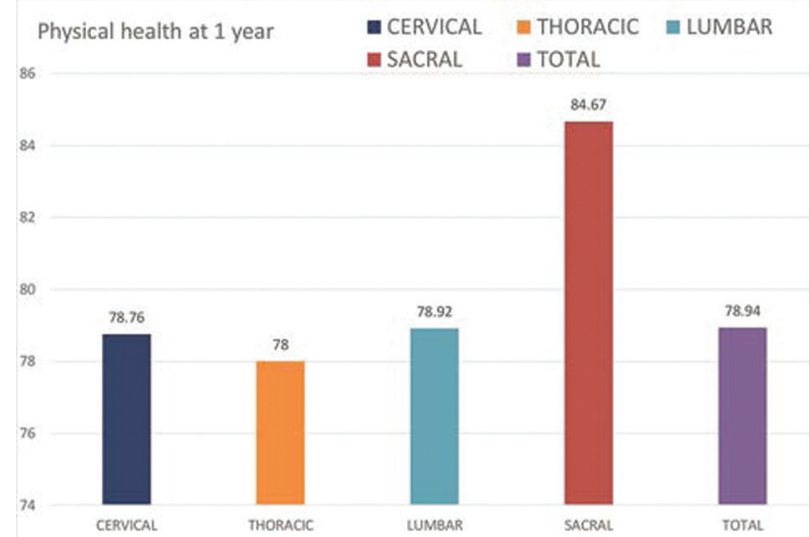

Fig. 2 Bar chart showing physical health domain score at 1 year.

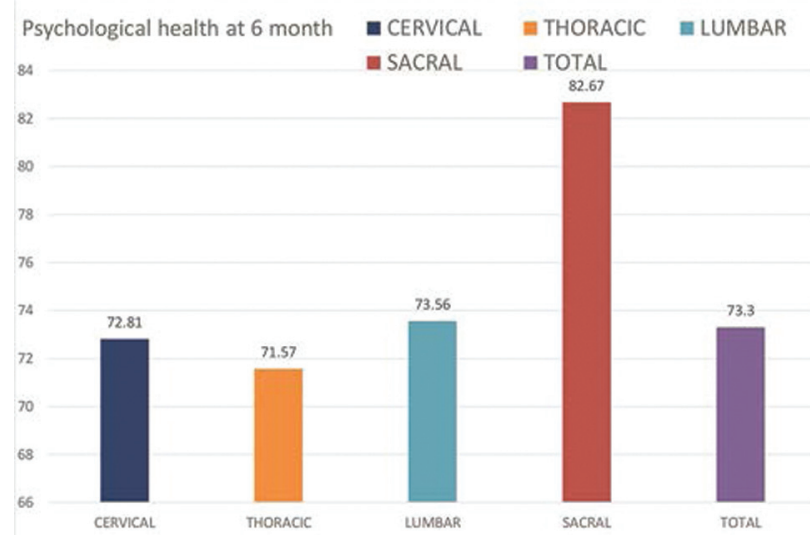

Fig. 3 Bar chart showing psychological health score at 6 month.

was 63.85 , for thoracic 66.86 , for lumbar 68.88 , and for sacral 75. At 6 months postinjury, the mean score was 73.3 , for the cervical subgroup it was 72.81 , for thoracic 71.57 , for lumbar 73.56, and for sacral 82.67. At 1 year postinjury, the mean score was 78.03 , for the cervical subgroup it was 78.9 , for thoracic 77.16 , for lumbar 78.92 , and for sacral 84.67 (-Figs. 3-4).

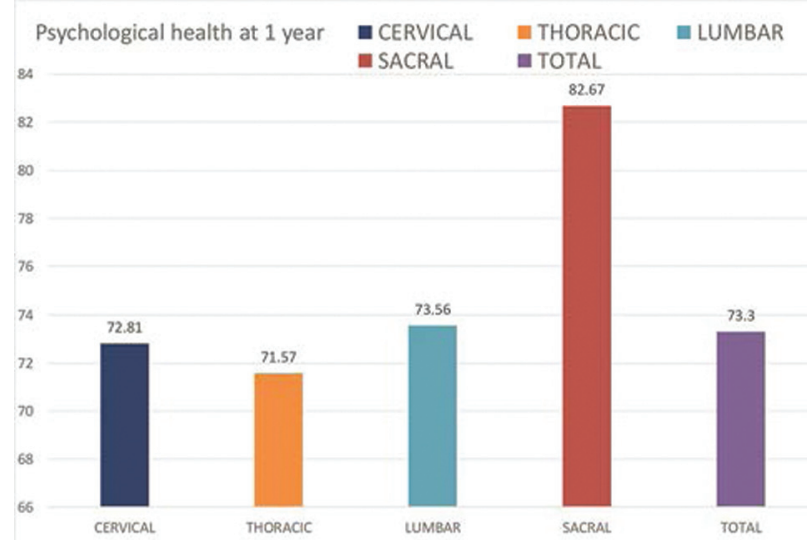

Fig. 4 Bar chart showing psychological health score at 1 year.

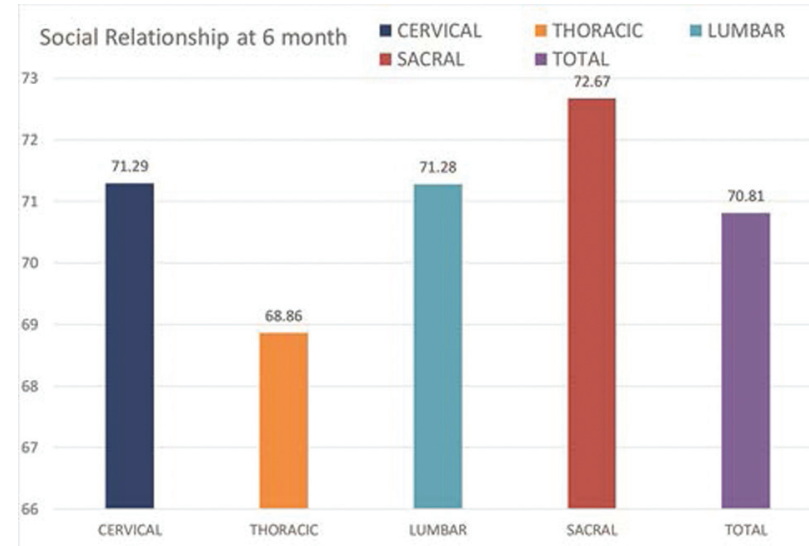

Fig. 5 Bar chart showing social relationship score at 6 month.

In the immediate postinjury status till the end of first month $60 \%$ of them required psychological counseling and medication in the form of anxiolytics and antidepressants. The number of sessions with psychiatrists was found to be directly proportional to the severity of motor impairment in the immediate posttrauma period. Thinking, learning, memory, and concentration were the main factors which improved at the end of 6 months and 1 year.

Social relationship: At onset of injury, total social relationship score mean was 63.47. For the cervical subgroup it was 60.62 , for thoracic 63.86 , for lumbar 66 , and for sacral 65.33. At 6 months postinjury, the mean score was 70.81 , for the cervical subgroup it was 71.29 , for thoracic 68.86 , for lumbar 71.28 , and for sacral 72.67. At 1 year postinjury, the mean score was 76.3 , for the cervical subgroup it was 78 , for thoracic 74.14 , for lumbar 76.12 , and for sacral 76 (-Figs. 5-6).

Personal relationships and social support were the main factors which were a major determinant up to 6 months. Patients with close relatives as caregivers did better as compared to others. The attitude of the caregivers was found to be playing a significant role in improving the social relationship. Younger patients with strong social support were found to give lesser credence to sexual activity. 


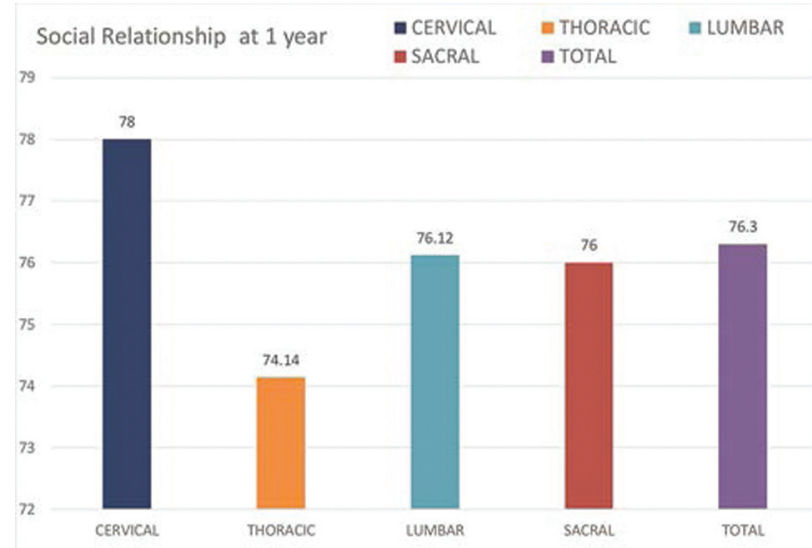

Fig. 6 Bar chart showing social relationship score at 1 year.

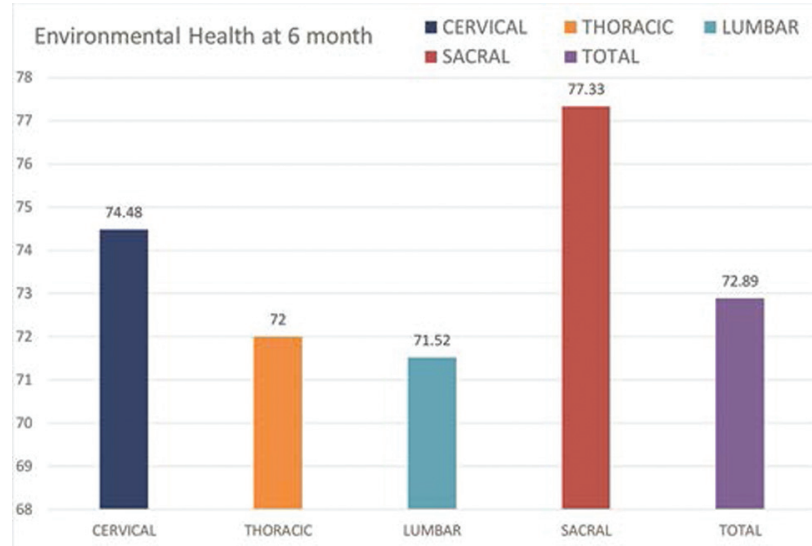

Fig. 7 Bar chart showing environmental health score at 6 month.

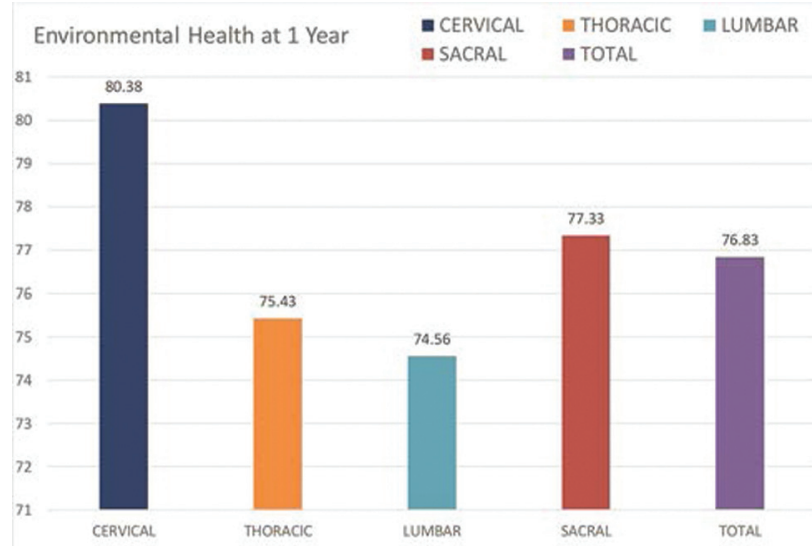

Fig. 8 Bar chart showing environmental health score at 1 year.

Environmental health: At onset of injury, total environmental health score mean was 67.25. For the cervical subgroup it was 66.35 , for thoracic 68.29 , for lumbar 67.32 , and for sacral 69.67. At 6 months postinjury, the mean score was 72.89 , for the cervical subgroup it was 74.48 , for thoracic 72 , for lumbar 71.52, and for sacral 77.33. At 1 year postinjury, the mean score was 76.83 , for the cervical subgroup it was 80.38 , for thoracic 75.43 , for lumbar 74.56 , and for sacral 77.33 (-Figs. 7-8).

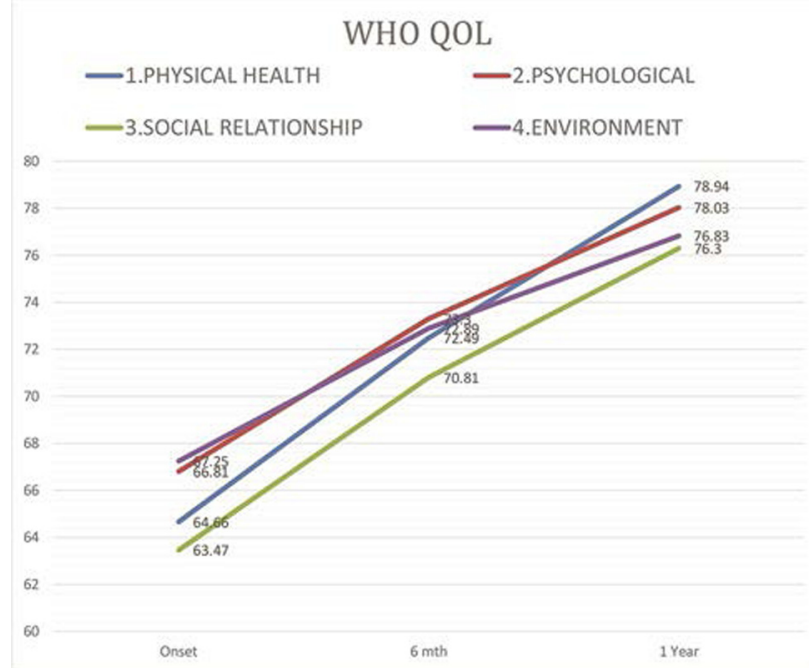

Fig. 9 Chart showing overall World Health Organization Quality of Life (WHO QOL) score traced for 1 year.

Compared to the other three domains environmental factor scores showed the least improvement. Patients undergoing management in rehabilitation centers with facility of motorized mobility assisting devices and occupation therapy facilities scored better at the end of 1 year.

The overall WHO QOL score when traced for 1 year showed that the maximum improvement in all four domains was in the first 6 months. At the end of 1 year maximum improvement was seen in the physical health domain (-Fig. 9).

\section{Result}

Our study showed that spinal injury mainly affects males $(82.4 \%)$ in the age groups of 30 to 50 years (41.2\%). Most common observed mechanism was fall from height (42.6\%) followed by RTA (19.1\%). Patients having cervical injury were more prone to develop neurogenic bladder (76.92\%). We found incomplete injuries (76.47\%) more than the complete injuries (23.52\%), cervical spine injuries being the most common (38.2\%). The overall mortality rate following spinal injury in our study was $7.35 \%$. Majority of patients underwent surgical intervention (54.41\%). We observed a gradual neurological, clinical, and QOL domain improvement over a follow-up period of 1 year. The improvement being maximum in the initial 6 months followed by a relative plateau over further course of time. Our study showed the following results which can be summarized as follows:

1. Four domains studied included physical health, psychological health, social relationship, and environmental health factors. Of this, physical health was a major determinant of QOL till the end of 1 year.

2. Pain and degree of motor impairment was a major predictor of QOL influencing all domains.

3. Quadriplegics as compared to paraplegics and complete injury and compared to incomplete injury were found to have a lower score in the initial 6 months. 
Table 1 Study comparison with similar studies worldwide

\begin{tabular}{|c|c|c|c|c|c|c|c|c|c|}
\hline $\begin{array}{l}\text { Study done so } \\
\text { far }\end{array}$ & $\begin{array}{l}\text { Time as an } \\
\text { important } \\
\text { predictor of } \\
\text { QOL }\end{array}$ & $\begin{array}{l}\text { Important } \\
\text { physical } \\
\text { factors } \\
\text { determining } \\
\text { QOL }\end{array}$ & $\begin{array}{l}\text { Important } \\
\text { psychological } \\
\text { factors }\end{array}$ & $\begin{array}{l}\text { Important } \\
\text { environmental } \\
\text { predictors }\end{array}$ & $\begin{array}{l}\text { Important } \\
\text { social } \\
\text { factors }\end{array}$ & Depression & $\begin{array}{l}\text { Marital } \\
\text { status }\end{array}$ & $\begin{array}{l}\text { Importance } \\
\text { of physical } \\
\text { factor in } \\
\text { determining } \\
\text { long-term } \\
\text { QOL }\end{array}$ & $\begin{array}{l}\text { Important take } \\
\text { away }\end{array}$ \\
\hline $\begin{array}{l}\text { Lude et al, } \\
2014 \\
(n=292)\end{array}$ & Yes & $\begin{array}{l}\text { Pain } \\
\text { Lesion level } \\
\text { (tetraplegia } \\
\text { versus para- } \\
\text { plegia) } \\
\text { Lesion type } \\
\text { (complete } \\
\text { versus } \\
\text { incomplete) }\end{array}$ & $\begin{array}{l}\text { Appraisals } \\
\text { Coping } \\
\text { strategies }\end{array}$ & $\begin{array}{l}\text { Level of } \\
\text { mobility }\end{array}$ & $\begin{array}{l}\text { Social } \\
\text { support }\end{array}$ & $\begin{array}{l}\text { Important } \\
\text { factor }\end{array}$ & Inconclusive & $\begin{array}{l}\text { Not clear } \\
\text { relationship }\end{array}$ & $\begin{array}{l}\text { Psychological } \\
\text { health showed } \\
\text { maximum increase } \\
\text { from } 6 \text { to } \\
12 \text { months. } \\
\text { Physical health } \\
\text { showed maximum } \\
\text { increase in first } 6 \\
\text { months }\end{array}$ \\
\hline $\begin{array}{l}\text { Shin et al, } 2012 \\
(n=106)\end{array}$ & Yes & $\begin{array}{l}\text { Motor abili- } \\
\text { ty. Not stud- } \\
\text { ied motor } \\
\text { deficits in } \\
\text { detail }\end{array}$ & $\begin{array}{l}\text { Mood } \\
\text { Coping } \\
\text { strategies }\end{array}$ & $\begin{array}{l}\text { Level of } \\
\text { mobility }\end{array}$ & $\begin{array}{l}\text { Social } \\
\text { support } \\
\text { Interper- } \\
\text { sonal } \\
\text { relation }\end{array}$ & $\begin{array}{l}\text { Majority of SCl } \\
\text { suffer from } \\
\text { depression }\end{array}$ & $\begin{array}{l}\text { Unmarried } \\
\text { fare better }\end{array}$ & $\begin{array}{l}\text { Not significant } \\
\text { in long term }\end{array}$ & $\begin{array}{l}\text { Depression, maxi- } \\
\text { mum in first } 6 \\
\text { months }\end{array}$ \\
\hline $\begin{array}{l}\text { Middleton } \\
\text { et al, } \\
2007 \\
(n=106)\end{array}$ & $\begin{array}{l}\text { Inconclu- } \\
\text { sive }\end{array}$ & $\begin{array}{l}\text { More on le- } \\
\text { sion level } \\
\text { Inconclusive } \\
\text { on lesion } \\
\text { type }\end{array}$ & $\begin{array}{l}\text { Coping } \\
\text { strategies }\end{array}$ & Mobility level & $\begin{array}{l}\text { Inconclu- } \\
\text { sive on } \\
\text { social } \\
\text { support }\end{array}$ & $\begin{array}{l}\text { Depression } \\
\text { and poor QOL } \\
\text { linked to self- } \\
\text { efficacy tar- } \\
\text { geted toward } \\
\text { SCI }\end{array}$ & $\begin{array}{l}\text { Inconclusive } \\
\text { on marital } \\
\text { status }\end{array}$ & Inconclusive & $\begin{array}{l}\text { Self-efficacy is an } \\
\text { important factor } \\
\text { determining QOL }\end{array}$ \\
\hline $\begin{array}{l}\text { Our study, } \\
2018 \\
(n=68)\end{array}$ & Yes & $\begin{array}{l}\text { Neuropathic } \\
\text { pain } \\
\text { Lesion level } \\
\text { Lesion type }\end{array}$ & $\begin{array}{l}\text { Coping } \\
\text { strategies }\end{array}$ & Mobility level & $\begin{array}{l}\text { In } \\
\text { conclusive }\end{array}$ & Strong factor & $\begin{array}{l}\text { All patients } \\
\text { studied } \\
\text { were } \\
\text { married }\end{array}$ & $\begin{array}{l}\text { Chronic pain } \\
\text { was the only } \\
\text { significant } \\
\text { physical factor }\end{array}$ & $\begin{array}{l}\text { All domains show } \\
\text { maximum im- } \\
\text { provement in first } \\
6 \text { month thereafter } \\
\text { it plateaus }\end{array}$ \\
\hline
\end{tabular}

Abbreviations: QOL, quality of life; $\mathrm{SCl}$, spinal cord injury.

4. Degree of motor impairment in the first month directly correlated with psychiatric intervention requiring counseling and pharmacotherapy.

5. Strong moral and social support by patients' caregiver had a significant impact in improving the QOL score in all domains.

6. Maximum improvement in all domains occur in the first 6 months.

7. Patients in rehabilitation centers along with a strong supportive caregiver fare better in long term as compared to patient undergoing the same in nonspecialized centers.

Literature so far published regarding QOL analysis in SCI patients support most of the findings which have emerged from our study. ${ }^{1-3}$ All the comparative studies show that there is a definite improvement in QOL with passage of time. Maximum improvement is seen in the initial 6 months to 1 year. The level of SCI takes precedence over completeness of SCI (-Table 1).

\section{Discussion}

The WHO Mental Health Division's Quality of Life Group considers QOL as the individual's perception about his position in life in the context of the culture and value systems he lives in, considering his objectives, expectations, standards, and concerns. ${ }^{4}$ This Group elaborated the WHO Quality of Life - 100 and its short version, called the WHO QOL-BREF, in which a crosscultural approach is adopted, as well as three aspects regarding the QOL concept: subjectivity (individual perception of his life), multidimensionality (understanding about the different dimensions of life), and both positive and negative assessment elements.

SCI patients are vulnerable to the injury and its squeal occurring from the phase of rehabilitation to the community reinsertion phase. Physical problems that can affect these patients include pressure ulcers and urinary tract infection, which affects at least 35\% of patients. Pressure ulcers can result in severe medical and psychosocial complications. These factors increase morbidity, health care costs, and have a direct bearing on individuals' QOL. ${ }^{5}$ Other problems associated with SCI are depression, affecting $25 \%$ of men and $47 \%$ of women, transient amenorrhea, affecting $60 \%$ of women, and neuropathic pain, occurring in 34 to $94 \%$ of victims. In patients suffering injuries at T6 or above this level develop autonomic dysreflexia, characterized by a dangerous increase in blood pressure, orthostatic hypotension, thermo dysregulation, and vasomotor abnormalities. ${ }^{6,7}$ With advancement in the understanding of SCI and incorporation of bioengineering technology, physical recovery has been the main focus but complete cure continues to remain elusive. Our longitudinal prospective study shows that there is a lot of scope for intervention in social, psychological, and environmental factors to improve QOL. Appropriate targeted intervention in improving these factors has a definite role in improving the QOL of these unfortunate victims.

\section{Conclusion}

All patients with SCI show improvement with time. Although physical domain is the main predictor of QOL at time of injury, the other domains play an important role in the later 
stages. Improved functional status, alleviation of pain, good social skills, and high self-efficacy are some of the factors which play an important role in improving overall QOL. Unfortunately, these factors seem to be undermined in developing countries. Further longitudinal research is suggested to clarify the mutual adjustment process of people with SCI and their close persons. Our study shows that the SCI victim requires intervention in physical, mental, psychological, and social domains so that we can integrate them back to their social milieu with high morale and self-esteem.

\section{Conflict of Interest}

None declared.

\section{References}

1 Middleton J, Tran Y, Craig A. Relationship between quality of life and self-efficacy in persons with spinal cord injuries. Arch Phys Med Rehabil 2007;88(12):1643-1648
2 Shin JC, Goo HR, Yu SJ, Kim DH, Yoon SY. Depression and quality of life in patients within the first 6 months after the spinal cord injury. Ann Rehabil Med 2012;36(01):119-125

3 Lude P, Kennedy P, Elfström ML, Ballert CS. Quality of life in and after spinal cord injury rehabilitation: a longitudinal multicenter study. Top Spinal Cord Inj Rehabil 2014;20(03):197-207

4 Fleck MPA, Louzada S, Xavier Met al.Aplicação da versão em português do instrumento abreviado de avaliação da qualidade de vida "WHOQOL-bref".. Rev Saude Publica 2000;34(02): 178-183

5 Lidal IB, Veenstra M, Hjeltnes N, Biering-Sørensen F. Healthrelated quality of life in persons with long-standing spinal cord injury. Spinal Cord 2008;46(11):710-715

6 Singh R, Singh R, Rohilla RK, Siwach R, Verma V, Kaur K. Surgery for pressure ulcers improves general health and quality of life in patients with spinal cord injury. J Spinal Cord Med 2010;33(04): 396-400

7 de França IS, Coura AS, de França EG, Basílio NN, Souto RQ. Quality of life of adults with spinal cord injury: a study using the WHOQOL-BREF [Portuguese]. Rev Esc Enferm USP 2011;45(06): 1364-1371 